\title{
BIJDRAGEN \\ TOT DE GESCHIEDENIS DER RECHTSPRAAK BIJ DE VEREENIGDE OOSTINDISCHE COMPAGNIE.
}

DOOR

Dr. F. W. STAPEL.

II.

Eenige jaren geleden heeft Professor Van Vollenhoven er op gewezen, dat men in den Compagniestijd geen studie van het adatrecht kon verwachten, maar dat het niettemin treffend is om te zien, ,hoe eenerzijds losse personen voor-en-na stukken adatrecht in handen nemen, en hoe anderzijds de compagnie zelf voor-en-na aanleiding vindt, om op practischen grond zich in te laten met adatrecht" ${ }^{1}$ ). Wij willen thans een en ander mededeelen omtrent in den Compagniestijd opgerichte colleges van rechtspraak over inheemschen, welke zich richtten, of althans heetten te richten, naar het volksrecht, en die, op alle plaatsen waar zij tot stand kwamen, toen reeds den thans nog gebruikten naam van Landraad droegen. Over Landraden op Ambon en Java is al een en ander geschreven; voor zoover ons bekend nog niet over die op Ceilon; daarom zullen wij met de laatste beginnen.

Vóór de komst der Europeanen regeerde de „Keyser” van Kandia als onbeperkt heerscher over het geheele eiland, met uitzondering van het in het uiterste Noorden gelegen Jaffenapatnam, dat een afzonderlijk koninkrijk was. Het land was verdeeld in corles - districten - bestuurd door een ambtenaar, die den titel droeg van corale. Boven den corale stond de disava ${ }^{2}$ ), hoofd van twee of meer corles; zijn gebied wordt in 's Compagnies papieren gewoonlijk aangeduid als dessavonye of dessaveschap, en wel omschreven als gewest of provincie. De disava was zoowel besturend als rechtsprekend ambtenaar, en als zoodanig, mutatis mutandis, te vergelijken met den Javaanschen regent van die dagen.

1) De Ontdekking van het Adatrecht, blz. 5 en volgende.

2) Dit woord is verwant met het Sanskrit en Javaansch desa, dat oorspronkelijk landstreek beteekent. 
Toen de Compagnie zich in het midden der 17 de eeuw had meester gemaakt van de kaneel-produceerende gewesten van Ceilon - in hoofdzaak de vlakke landen van den Zuid- en Westkant, van de zeekusten tot aan het gebergte - behield zij daar voor haar ambtenaren, die onder den gouverneur belast waren met het interne bestuur over bepaalde deelen van dit gebied, den titel dessave. Het is een der zeer weinige voorbeelden, dat een Nederlandsch ambtenaar een inheemschen titel droeg.

's Compagnies gebied op Ceilon, buiten de steden, bestond uit vier dessavonyen, en wel Jaffenapatnam, Colombo, Gale en Mature. Het platteland van Gale evenwel wordt steeds Gale-corle genoemd, en de besturende ambtenaar heette daar ,opsiender”, doch dit was slechts een verschil in naam, overgebleven uit den inheemschen tijd, toen Gale inderdaad een corle was. Bij de Compagnie was dit gewest, wat bestuur en rechtspraak betreft, gelijk aan de dessavonyen.

Ook de Nederlandsche dessave had, behalve zijn bestuursfunctie toezicht op het kaneelschillen, zorg voor onderhoud van gebouwen, wegen en bruggen, controle op de vidana's of dorpshoofden en andere inheemsche ambtenaren - een rechterlijke taak te vervullen. Deze beperkte zich tot zaken tusschen inheemschen onderling, en dan binnen zekere grenzen. Een Instructie van 1707 voor den dessave van Colombo omschrijft zijn rechtsprekende taak als volgt ${ }^{1}$ ):

„Binnen 't district van Colombo heeft de dessave alleen recht, om alle dieven, doodslagers en andere quaaddoenders te vervolgen, vangen, en die aan den fiscaal-independent ${ }^{2}$ ) over te leveren, dog gemeene delicten, als van verzuim, mesuses etc ${ }^{\mathrm{n}}$ zal hij door boete, rotang- en sjambokslagen, ook wel door de keten - mits t'elkens van 't laatste den gouverneur waarschuwende - mogen corrigeeren.

Ook mag hy alle geschillen der Inlanders hooren en afdoen, die niet boven de 10 rijksdaalders monteeren, bij arrest of zonder appel, dog die daarboven tot 80 rijksdaalders gaan, werd 't appel aan den civilen raad toegestaan, mits 5 rijksdaalders namptissement voor 't faut appel, zo 't zo bevonden werd. Dog geen civile zaken, die somme [ 80 rijksdaalders] te boven gaande, zal hij mogen behandelen, tenzij partyen wederzijds ten zynen overstaan eenige goede mannen wilden verkiezen, waarvan dan een bondig compromis moet werden gemaakt onder zekere boete, by partyen te begrooten, zo een van beide met de uytspraak niet tevreede was, of onder willige condemnatie van den

1) Afgedrukt bij Valentijn V, Ib, Ceylon, blz. 304 e.v.

2) Namelijk bij den Raad van Justitie in de stad Colombo. 
civielen raad, of die van Justitie, indien 100 rijksdaalders surpasseeren.

Dog om de executie van alle vonnissen, boven de 10 rijksdaalders, na stijl en form te doen geschieden, zoo zullen die bevorens aan den civilen raad moeten gepresenteerd werden, die zonder verder onderzoek, dan of den dessave of de goede mannen d'uytspraak gedaan hebben, wanneer de 10 dagen of de fatalia van 't appel verloopen zullen zijn, de executie daarop zullen doen decerneeren, zoals 't na stijl van rechten gebruikkelijk is".

Het ambt van dessave was lang geen sinecure, vooral doordat geschillen omtrent landbezit aan de orde van den dag waren. Er bestonden op Ceilon van oudsher een soort kadaster-lijsten, thombo's genaamd, en door de Compagnie vaak door ,landrollen” vertaald ${ }^{1}$ ), doch die waren meest onvolledig en duister gesteld, wat tot voortdurende moeilijkheden leidde. Gouverneur en raad van Ceilon hebben er de regeering te Batavia meermalen op gewezen, dat het den dessave's niet wel mogelijk was, alle onderdeelen van hun ambtstaak naar behooren te vervullen ${ }^{2}$ ), en dit is een der redenen geweest, om het rechtsprekende gedeelte van hun taak over te dragen aan Landraden.

Gerrit de Heere, van 1697 tot 1702 gouverneur van Ceilon, maakte van ultimo Maart tot 29 September 1698 een inspectiereis om het geheele eiland, van Colombo via Gale, Mature, Trinkomale en Baticalo aan de Oostkust, Jaffenapatnam en Negombo, naar Colombo terug ${ }^{3}$ ). Vooral in Mature bleken vele en diepgaande kwesties te bestaan over landbezit, en er heerschte, tengevolge daarvan, een geprikkelde stemming. De Heere besprak de zaak met verschillende inheemsche hoofden, ,haar verstaende op den Singalese costumen, wetten, oud heren voorkomens". In aansluiting op die besprekingen maakte hij met zijn raad een nieuwe verdeeling der gronden, vruchtboomen, rechten

1) Ik ontmoette ook het woord hoofdthombo's, voor naamlijsten der ingezetenen, waaruit zou zijn af te leiden, dat thombo eenvoudig lijst of register beteekent. Zie ook Van Ronkel in Bijdragen Koninklijk Instituut, deel 75, 1919, blz. 278. Het wordt echter bij voorkeur gebruikt voor: register der landerijen.

2) Zie vooral ook de beneden te bespreken Memorie van Van Imhoff.

${ }^{3}$ ) Het zeer uitvoerige Daghregister dier reis vindt men in afzonderlijken band op het Rijksarchief onder de „Overgecomen papieren van Ceylon, 1699” eerste deel. Het beslaat 381 dubbele folio's en geeft tal van tabellen en teekeningen. 
der hoofden op bepaalde landen en dorpen, etc. ${ }^{\mathbf{1}}$ ). Den 25 sten Juni 1698 besloot de gouverneur met zijn raad ,,alhier voortaan weder te houden en op te rechten een ordinaire civielen Landraad, als voormaals in een seer goet gebruyck is geweest; en zal dien raad moeten bestaan in den $\mathrm{E}$. dessave, den luytenant off vaandrigh, den pakhuysmeester ende vier modeljaars ${ }^{2}$ ), nevens een g'authoriseert clercq, die kort aantekeningh ter rolle moet doen" ${ }^{3}$ ).

Terloops zij opgemerkt, dat de Landraad, althans op Ceilon, dus zijn naam dankt aan het feit, dat hij in allereerste instantie uitspraak moest doen in geschillen over landbezit. Bij resolutie van GouverneurGeneraal en Rade van 25 September 1699 werd de instelling van een Landraad op Mature geapprobeerd, als ,dienstigh voor de ruste”, en in haar brief naar Ceilon d.d. 22 October 1699 verklaart de Hooge Regeering zoodanigen Landraad voor ,nut en dienstigh” aan te zien.

Het zal uit het voorgaande duidelijk geworden zijn, dat Landraad en dessave's bij het uitspraak doen in geschillen over de thombo's zich dienden te richten naar het volksrecht. Of zij - althans de dessave's - daarvan steeds voldoende op de hoogte waren, mag worden betwijfeld, en het is waarschijnlijk daaraan te danken, dat Mr. Cornelis Joan Simons, van 1703 tot 1707 gouverneur van Ceilon, en te voren onder meer vice-president van den Raad van Justitie te Batavia, in Augustus 1706 opdracht gaf, het volksrecht op te teekenen. Met die taak belastte hij Claes Isaacqz, dessave van Jaffenapatnam, die de Compagnie reeds 37 jaren, en wel steeds op Ceilon, had gediend. In den titel noemt Isaacqz zijn compendium, dat in het begin van 1707 gereed was ${ }^{4}$ ) ,Jaffanapatnamse oude Costuymen en Insettingen, waarnaar men gewoon is desen landaard in civiele saken, als erffenissen, adoptie, gifte, naasting, coop en verkoop, verpanding

1) Het Daghregister geeft ook een „Landbeschryvinge of tombo” met kaart.

2) Modliaar is de titel van verschillende inlandsche ambtenaren, maar meest van hoofden der inheemsche krijgslieden. Gewoonlijk had de modliaar 3 rantjes onder zijn bevelen; een rantje is een afdeeling van 24 man. Ook komen voor mahamodliaars of groot-modliaars. De orgineele spelling is moedalijar. Zie Van Runkel, 1.c.

${ }^{3}$ ) Het is mij niet duidelijk, wat de resolutie bedoelt met ,weder" oprichten en „als voormaals in een seer goet gebruyck is geweest", daar ik in de Ceilonsche rapporten van vroeger jaren niets van zoodanigen Raad heb kunnen vinden.

$\left.{ }^{4}\right)$ Dit volksrecht, Thesawalemei, is afgedrukt in de Bijdragen van het Koninklijk Instituut, 75, 1919, blz. 240-280. Zie ook Van Vollenhoven, De Ontdekking van het Adatrecht, blz. 8; Het Adatrecht van Ned.-Indië, I, blz. 16 en II, blz. 342 . 
en ontlossing van landeryen en thuynen etc. [te berechten]". Met dit „men" kan, naar wij meenen, niemand anders bedoeld zijn dan de dessave.

Bij de periode van wanbestuur der Ceilonsche gouverneurs Petrus Vuyst, 1726-1729, en Stephanus Versluys, 1729-1734, zullen wị hier niet stilstaan; de eerste liet in 1732 zijn hoofd op het schavot te Batavia, de tweede bracht een aantal jaren daar ter plaatse in de gevangenis door. Zijn opvolger, Diederik Domburg, was niet bij machte, de al lang onder de bevolking heerschende gisting tot rust te brengen; de chalia's of kaneelschillers staakten, 's Compagnies koffietuinen werden verwoest. Onder deze omstandigheden kwam $23 \mathrm{Juli}$ 1736 de man op Colombo aan, die door een wijs beleid en groote werkzaamheid den Ceilonschen Augiasstal zou reinigen: Gustaaf Willem, baron van Imhoff. Den 7den Maart 1737 begon hij zijn eerste landreis, naar de Zuiderdistricten van Ceilon ${ }^{1}$ ). Ook nu heerschten vooral in Mature groote verwarring en ontevredenheid, met name ,,veelvuldige confusiën en disputen over den eygendom der gronden, en de wettigheid of onwettigheid der daarvan voorhanden zijnde blyken". Daartoe had niet weinig bijgedragen het feit, dat de Landraad in de laatste jaren weinig of niet had vergaderd; gevolg: „,veelvuldige, langdurige en byna indecisible processen, die thans onder de gemeente over dat stuk en vogue, en voor deselve also ruineus, als voor den regter difficil en genoegzaam ondoorkomelijk zijn".

Ten einde hierin verbetering te brengen, ,,mitsgaders tot herstellinge van goede politie en justitie onder de gemeente, ten hoogsten nodig bevonden wierd de revificatie of wederopregting van den byna versturvenen Landraad, die t' sedert twee jaren zodanig gebleeven is in den staat van inactiviteit, waartoe het scheind dat de revolte en troubles in het land dat collegie, eertijds met zulken goeden oogmerk gestigt.... en door Haar Hoog Ed. by missive naar dit eyland, van den 22 Octoher 1699, zoo zeer gelaudeert, in dese bose dagen hebben gebragt, dat het thans onder de menschen in het land alomme in de uytterste confusie en verwarring is geraakt, doordien zy niet van den anderen kunnen komen, wanneer eenige verschillen onder haar komen te rysen, die anders door dese vergaderinge als haren compe-

1) Zie voor Van Imhoff als gouverneur van Ceilon het artikel van Gijsberti Hodenpijl in het hierboven genoemde deel der Bijdragen Kon. Instituut, blz. 481-624. Aldaar ook een kort uittreksel uit het journaal zijner landreizen. Het volledige dagboek der hierboven besproken eerste reis vindt men in de „Overgecomen brieven van Çeylon, 1738", derde deel, op hẹt Rijksarchief. 
tenten regter werden gedecideert. Zoo is dan teffens goedgevonden en verstaan, dat voormelde Landraad, hebbende den E. dessave tot president, en tot leden die van den raad van Mature, en zooveel modliaars, als zig hier ter plaatse bevinden, weekelijx tweemaal wederom vergaderen zal op twee vaste dagen, te weten des Dingsdags en Vrydags, opdat de menschen in 't land daarop staat kunnen maken, om haar zaken daarna te schicken, en also een iegelijk goed regt t' erlangen, dat ook aan haar op de generale paresse zal werden bekend gemaakt".

Zoo was de Landraad hersteld, en hield sedert geregeld zijn zittingen.

In 1740 trok Van Imhoff naar Batavia, om sessie te nemen in Rade van Indië. Den 12den Maart van dat jaar droeg hij het bestuur over aan Willem Maurits Bruynink, en stelde dezen een Memorie ter hand, om zich bij zijn bestuurstaak naar te richten. Dit uiterst belangrijke stuk is in het Nederlandsch nog nimmer afgedrukt, wel in het Engelsch ${ }^{1}$ ). Wij laten hier het gedeelte er uit volgen, dat betrekking heeft op den Landraad van Mature, en dat ook daarom van zooveel belang is, omdat het de aanleiding werd tot het oprichten van meerdere Landraden op Ceilon.

„Het is bekend, dat hetgeene men 's Compagnies besittingen op Ceylon noemen kan, buyten Jaffenapatnam, bestaat in drie hooftdeelen, de Colombose dessavonie, de Gale-corle, en de dessavonie van Mature. Over ieder van dezelve is een Europees gequalificeerd dienaar als landregent gesteld, denwelken op Mature toegevoegt is een Landraad, tot afdoeninge van de geschillen onder den anderen, een collegie, genoegsaam bekend en beschreeven by voorgaande memoriën, ook nog laast aangehaald by mijn dagregister van $\mathrm{a}^{\circ} 1737$, om daarvan in deesen niets meer te erinneren, als dat dies voortgang en activiteyt onverhindert moet werden gehouden, opdat aan het oogmerk der instelling van dien voldaan, en de gemeene man geholpen werde. Ten dien eynde sal het niet quaad zijn de jongst gestelde ordre ter oversending van de copia-actens dier vergaderinge in effect te houden, opdat een gouverneur alhier ${ }^{2}$ ) zelfs mooge zien, hoe dikwils. deese byeenkomsten werden gehouden, om voor te koomen het versloffen

1) Van de Memorie van Van Imhoff zijn eenige exemplaren op het Rijksarchief voorhanden; hier wordt geciteerd die onder Koloniaal archief no. 11521. De Engelsche vertaling verscheen in 1911 te Colombo; ze is het werk van Sophia Pieters, Dutch translator.

2) Op Colombo. 
van dezelve, dat vorige dessaves van Mature zig meenigmaal tot haar gemak hebben aangewend, en anders hier zo ligt niet te ontdekken is.

In de Colombose dessavonie en Gale-corle daarentegen fungeerd een dessave en opsigter alleen ${ }^{1}$ ), en in dezelve is zodaanigen Landraad niet, dogh ik weet niet waaromme, aangezien het my al lange toegescheenen heeft, dat het veel meer dan eenes menschen werk is, alle de pligten, die aan deesen importanten landsdienst g'accrocheert zijn, in alle de deelen desselven naar behoren waar te neemen.

Dat nu de dingen, tot het wel waarnemen van deesen dienst gehoorende, wel zo veele zijn, dat men in eenige van dezelve wel zoude mogen admitteeren dit hulpmiddel eener inlandschen, of liever ondergemengde, vergaderinge tot afdoeninge van de geschillen der inlanders onder den anderen, hetwelke nu aan den dessave alleen bevoolen blijft, dat zal iemand, die regt weet wat een zodaanig minister, en vooral een dessave van Colombo, te doen heeft, onmogelijk kunnen teegenspreeken.

Vooreerst moet een dessave alhier dagelijks klaar staan tot het aanhooren van hondert kleyne geschillen, tusschen de inlanders voorvallende, dewelke, wanneer zij van weynig belang zijn, ook alsnog wel aan zijn privative decisie souden kunnen verblyven, de groote en swaarder zaaken alleen voor den Landraad gereserveert houdende; en soude hierinne deese bepalinge kunnen werden gemaakt, dat alle kleyne delicten, waarom de straffe niet hooger kan gaan dan tot een kleyne geldboete, die weederom bepalende op uyterlijk 5 rijksdaalders, door den dessave alleen, wat hooger loopt door hem èn den Landraad zouden moeten beslist werden, en wat nogh daarboven en ook voor deese te zwaar valt, voor den gouverneur zelfs zoude dienen te koomen.

[Volgen nu de andere ambtsbezigheden van den dessave, buiten de rechtspraak].

In de vijfde plaatse, met attentie te kunnen vaceeren tot die onophoudelyke disputen over de eygendommen en bezittingen der landeryen, dewelke zoo veelvuldig zijn, dat zy alleen wel voor de helfte zodanigen minister kunnen g' occupeert houden, zo zy regt souden moeten behandelt werden, en moeten nu meenigmaal werden overgelaaten aan het onderzoek eeniger inlandsche bediendens, by den dessave dienst doende, die dan ook teffens de uytspraake daarover doen, met het uyten van haar gevoelen dienaangaande, zodat alzulcken

1) Het hoofd van de Gale-corle heette opsiender of opsigter. 
decisie veel meer voor die van den modliaar der attepattoe ${ }^{1}$ ) of den tolck van gemelde dessave, dan voor die van hem zelfs te considereeren is, vallende daardoor dan ook veelmaals uyt naar den sin van die bediendens, welkers konkelaryen en partialityten in dat stuck zeer veele zijn.

[Volgt een betoog over het leeuwenaandeel, dat kwesties over landbezit innemen in de zorgen van het inheemsche leven, gevolg van de onvolledigheid en duisterheid der thombo's of landbeschrijvingen].

$\mathrm{Nu}$ is er, naar mijn begrip, nòg eygentlyker, nòg zeekerder, nòg korter expedient om dit alles te redresseeren en vervolgens op een goeden voet te houden, als eenen zodaanige collegie van een Landraad alhier, dat niet alleen met gemak en meer eygenschap zodanigen onderzoek, als tot ontdekking van gelijk en ongelijk noodig is, maar ook veel zeekerder kan doen dan een dessave alleen, omdat desselfs leeden, zelfs voor de helfte inlanders zijnde, onmogelijk zo volkoomen met den anderen kunnen accordeeren, om eenparig de overige, der tale niet kundig, door verkeerde rapporten of translatiën te misleyden, gelijk daarenteegen in de decisie van een dessave alleen dikwils geschiet en geschieden kan. En het is ook het kortsten, omdat een eerlijk dessave, thans in veel onzeekerheyt daaromtrent verkeerende, nu wel eens zoveel moeyte daaromtrend moet doen, ten einde niet, of zo min mooglijk, bedroogen te worden, als in dat collegie zoude behoeven te geschieden.

Ook is het de naaste, de gemakkelijkste en de zeekerste weg, om ooyt een goede thombo of landbeschryvinge van dit land te krygen, zulk een collegie alhier ${ }^{2}$ ) op te regten; en mooglijk zal de volgende daartoe noodige schikkinge ook wel op Mature van applicatie zijn, om tot een gewenscht einde daaromtrent te koomen, vermits men daar dog reeds zodanige collegie aan de hand heeft ${ }^{3}$ ).

Want genomen, dat hier eene half gedeelde vergaderinge van Europeesen en inlanders onder de naam van een Landraad wierd opgeregt, waarin den dessave zoude dienen te praesideeren, den fiscaal vice-praeses, en drie andere Europesche gequalificeerdens als leeden souden zijn, hebbende een van de scribenten, by den dessave dienst doende, of wel een ander pennist, tot scriba, en wyders gesterkt door

1) Attepattoe is de titel voor een inheemsch schrijver; de modliaar der attepattoe is het hoofd der klerken.

2) Op Colombo.

3) Bedoeld wordt, dat mogelijk ook de Landraad van Mature een nieuwe thombo zou kunnen opmaken voor die dessavonye. 
den mahamodliaar van des gouverneurs porte ${ }^{1}$ ), den modliaar en tolk van den dessave - een tweede modliaar van de porte, gelijk thans, om den ouderdom van den eersten, niet steeds gecreërt werdende neevens de modliaars en coraals van de Salpitty- en Hewagam-corle, als naby leggende, tot permanente en concludeerende, mitsgaders de andere modliaars van de overige corles, item de mohamdirams ${ }^{2}$ ) van des gouverneurs lijfwagt, wiens beurt het is, tot adviseerende leden, so zoude zodanigen collegie, alle weeken een dag daartoe vaceerende, zeer gemakkelijk kunnen effen houden alle geschillen, zo onder de gemeente over deese of geene voorvallen, als over de eene of andere voorregten, uyterlijkheeden, besittingen en andere dingen occureerende, tot groote ontlastinge van een dessave, die nu weekelijks tweemaal daartoe vaceerende, nog niet dan zeer gebrekkelijk het werk effen houden en een iegelijk aan het zyne helpen kan.

[Volgt een omschrijving van de wijze, waarop Van Imhoff meent dat de landraad een nieuwe thombo zou kunnen samenstellen].

Onmiddellijk na aankomst te Batavia reikte Van Imhoff een afschrift zijner Memorie aan den Raad van Indië over, en lichtte die bij de eerstvolgende Ceylonsche Besoignes mondeling toe. In haar vergadering van 14 Juli 1740 nam de Hooge Regeering in verband daarmede verschillende besluiten aangaande de defensie en het bestuur van genoemd eiland, waaronder ook het volgende:

„A1 verder gereflecteert sijnde op de consideratiën van gemelden Heer Van Imhof, aantonende de noodsakelijkheid om in de Colombose dessavonie en Gale-corle even soodanigen landraed aan te stellen, als dat gepractiseert werd in de dessavonie van Mature, ten fine nevens den dessave of opsiender der Gale-corle alle kleene en dagelijx voorvallende geschillen onder den Inlander af te doen, aangesien het veel meer dan eenes menschen werk is, alle de pligten, die aan den importanten dienst van Colombose dessave, off opsiender der Gale-corle, vast sijn, naar behooren waar te neemen, so is verstaan. de voorenstaande propositie na syne forme en inhoude te amplecteeren, en dienvolgende het presente ministerium op Ceylon aan te schryven, om sowel in de Colombose dessavonie, als in de Gale-corle, ten eynde voorschreven een landraad te erigeeren".

$\mathrm{Na} 1740$ had men dus op Ceilon drie Landraden.

1) De kapitein der inheemsche soldaten van het kasteel op Colombo.

2) Inheemsche luitenants. 
Thans een enkel woord over den Semarangschen Landraad, waarvan tot dusver wel iets meer bekend was dan van de Ceilonsche colleges ${ }^{1}$ ), doch welks geschiedenis niettemin nog eenige opheldering behoeft. Ook aan cleze instelling is de naam van Van Imhoff ten nauwste verbonden.

Nadat Cornelis Speelman den 15en Januari 1678 Semarang met omgeving voor de Compagnie had verkregen, breidde zich haar gebied langs deze kust geleidelijk uit, en in 1705 werd genoemde plaats geproclameerd tot hoofdstad der „Commandoreye van Java's Oostkust”. In ruil voor den steun, welken de Compagnie in de $1 \mathrm{e}$ en $2 \mathrm{e}$ Mataramische successieoorlogen verleende aan de door haar gewenschte pretendenten, verkreeg zij in 1708 en 1723 belangrijke uitbreiding van dit territorium. Moeilijke tijden maakte men hier door in de jaren van strijd, welke volgden op den Chineezenmoord te Batavia in 1740, en waarin, behalve de Compagnie en de Chineezen, ook Mataram en Madoera partij waren. Toen eindelijk de vrede hersteld was, ondernam Gouverneur-Generaal Van Imhoff in 1746 een inspectiereis naar de Oostkust $^{2}$ ), en, op Batavia teruggekeerd, nam hij het initiatief tot een algeheele reorganisatie van bestuur, defensie en rechtspraak in het wederom uitgebreide gebied, dat ten slotte bij resolutie van 20 Februari 1748 tot Gouvernement van Java's Noordoostkust werd verheven.

Wij laten nu volgen de resolutie van 30 November 1747 , welke de oprichting van een Landraad te Semarang vaststelde:

„Wyders door den heere Gouverneur-Generaal voorgesteld zijnde de noodzakelijkheyt, dat 'er op de judicature nadere ordre werde gestelt, omtrent alle de landen, onder de Compagnie op Java sorteerende, voor soo verre 'er eenige civile of crimineele saken voorvallen mogten tusschen Javaan en Javaan - alle gemengde zaken, 't zy Javaan en Europees, of ook een Javaan met een overwaller of andere uytheemsche natiën concerneerende, altoos blyvende onder het ressort van den raad van justitie tot Semarang, en in den Oosthoek ter eerster instantie op Sourabaya - zo wierd goedgevonden en verstaan :

dat tot Samarang sal werden geformeert een Landraad, bestaande

1) Zie voor den Landraad te Semarang: De Haan, Priangan IV, passim, vooral blz. 654; Kern, in Bijdragen Koninklijk Instituut, deel 83, 1927, blz. 410 en volgende.

$\left.{ }^{2}\right)$ Het Journal van deze reis is afgedrukt in Bijdragen Koninklijk Instituut, deel I, 1853, blz. 291-440. 
uyt seven der voornaemste regenten, onder de praesidie van den commandeur, sullende den adepatty van Samarang, nevens de Oosten Westerstrand-regenten altoos permanente leden van dien raad, dog de andere ambulatoir zijn voor twee of drie jaar, en by forme van nominatie van jaar tot jaar moeten voorgedragen werden ten getale van agt, om vier daaruyt te kiesen, sullende een boekhouder als scriba daarin fungeeren uyt de Europeese dienaren, nevens een Javaanse secretaris; en van voorschr. agt leden ${ }^{1}$ ) in het crimineele altoos seven moeten praesent zijn, als er iets gedisponeert werd; dog voor het overige dien landraad regt te laten spreeken en de saken afdoen naar de Javaansche wetten, voor so verre by ons tollerabel zijn, waarvan een compendium sal moeten geformeerd en ditheen gesonden werden ter visie en approbatie, om daaraan te kunnen verleenen de magt der uytvoering; terwijl in ieder district sal moeten gehouden werden één jaxa $^{2}$ ) of meer, na noodsakelijkheyt, en over alle deselve tot Samarang een grootjaxa of Javaanse fiscaal, om van de voorvallende delicten - dog de dagelijkse geschillen van weynig belang onder de gemeente daarvan uytgesloten, also die door de regenten moeten werden afgedaan, gelijk tot nog toe - notitie te nemen, en die voor den gemelden Landraad te beklagen; voorts alle crimineele vonnissen van dien raad sooveel mogelijk te doen executeren ter plaatse, daar de delicten zijn geperpetreerd ${ }^{3}$ ), dan wel ten minsten op de passebaan van den regent van dat district, opdat het quaad door den afschrik der aanschouwers des te efficatieuser ${ }^{4}$ ) werde gestuyt ; en van de vonnissen, by gemelde raad werdende gedecerneert, geen ander of hoger beroep te admitteeren, dan aan dese regeering direct, so het nodig mogte zijn; en ook alle doodvonnissen van dien alvorens aan dese tafel te approbeeren, ook in den aanstaande alle vonnissen des doods, door den raad van Justitie tot Samarang gewesen werdende omtrent allerly gecondemneerdens, en niet, gelijk tot hiertoe, na het g'arresteerde by resolutie van den 21 December 1708 is geschied, alleen van Europeesen, moetende ook nog by gemelde Landraad gehouden werden civile en criminele rollen van de saken, daarvoor gebragt werdende, en daervan jaarlijx copia na hierwaarts overgesonden".

In aansluiting bij deze resolutie zendt de regeering bij schrijven van 22 December 1747 order naar Semarang, om: 1o. dubbeltallen

1) Namelijk de Nederlandsche commandeur en zeven regenten.

2) Djaksa.

3) Zie voor dit beginsel ook De Haan, Priangan IV, blz. 689-690.

4) De copiist maakte hiervan essecatieuser. 
naar Batavia op te zenden ter benoeming van Landraadsleden, en 20 . maatregelen te nemen tot het samenstellen van een compendium van Javaansche wetten, in overleg met Mohamedaansche priesters en andere deskundigen! Reeds 1 Maart 1748 kon de regeering uit de inmiddels overgekomen voordracht tot leden benoemen ,,den tommongangh Marta Nagara van Damak, den ranga Adimangala van Caliwoengo, den ingabey ${ }^{1}$ ) Singa Widjaya van Candal, en den raden Tjacra-nagara van Pamalang; item tot Inlands fiscaal den raden Indramata". De eerste vier werden genoemd ambulatoire leden, omdat zij slechts voor een beperkten tijd - twee jaar - zitting hadden. Permanente leden waren bovendien ambtshalve de patih van Semarang en de z.g. Ooster- en Westerstrandregenten, d.w.z. die van de onmiddellijk aan Semarang grenzende gewesten.

Bij Generale Missive van 31 December 1747 schrijft Van Imhoff naar Nederland ${ }^{2}$ ), dat het zijn bedoeling is ,om van de voorschr. wetten en gebruyken der Javanen in het oordeelen over civile en criminele gevallen te formeeren een kleyn corpus of verzameling, om vervolgens daaraan te kunnen verleenen de magt der uytvoeringe, ten eynde alzoo die volkeren, die thans van onder de heerschappye des Soesoehoenangs onder die van de Compagnie zijn overgegaan, niet te ontnemen het natuurlijke voorregt - waarvan men haar, sonder onbillijkheyt en inconvenienten te verwekken, niet zoude kunnen doen desisteren - om na hare eygene landswetten, sooveel onder ons oppergezag geschieden kan, geoordeelt te worden, even als dat ook omtrent de Cheribonse, Preanger en Jacatrase bovenlanden in gebruyk is" ${ }^{3}$ ).

Het duurde nog bijna anderhalf jaar, voor het bedoelde corpus gereed was, zooals blijkt uit den volgenden brief van den gouverneur van Java's Noordoostkust aan de regeering te Batavia, de dato 10 April 1749:

„Buyten de Uw Hoog Edelheedens by gemeene eerbiedige letteren van huydigen datum gedaene seer submisse communicatie van den toestand deeser custe, is my thans wegens d'Inlandse zaaken, zoo uyt d' boven- als beneedenlanden - daar alles in rust en vrede is - geen andere stoffe, Uw Hoog Edelens attentie waardig, aan handen; gebruyke overzulx d' vryheyd, deese eenelijk te rigten ten geleyde van een Compendium der voornaamste Javaesche wetten, ingevolge $\mathrm{Uw}$

1) Versta : ngabehi.

2) Overgecomen brieven 1748 , eerste boeck.

3) Zie hiervoor De Haan, Priangan IV, hoofdstuk XXIV, blz. 613 en volgende. 
Hoog Edelheedens hooggevenereerde ordre by missive van 22 December 1747 geformeert, en nauwkeurig getrocken uyt 't Mahometaans wetboek Mogharaar, mitsgaders zooveel mogelijk met 't goddelijk, natuurlijk, borgerregt zoodanig samengebragt, dat daarna, ongekrenkt de Javaansche gewoontens en gebruykelijkheeden, met believen en goedvinden van Uw Hoog Edelens den Samarangschen Landraad over d'onderdaanen van 's Compagnies lande en districten regt en justitie zoude kunnen oeffenen, en de crimineele zaaken, zoowel als de civiele, uytspreeken en behandelen na d' poincten, daarby g' insereert. Hebbende voorts teffens ook de eere, Uw Hoog Edelheedens hiernevens eerbiedig te praesenteeren de by den Landraad op den 20, 22 en 25 Maart gevallene besluyten, en een bundel civille en crimineele procespampieren met dies bylaagen, consterende bij 't eerstgeciteerde besluyt, dat ten dien daage by de voorn. collegie goedgevonden is, om na nauwkeurig examinatie van 't voormelde Compendium, op d' ordres en bepaelingen, daarby vermeld, Uw Hoog Edelens hoogg'eerde approbatie te verzoeken, welk hierby dan met alle eerbied geschied. Onder de crimineele procespampieren bevinden zig twee vonnissen des doods.... etc.".

Onder de Overgecomen papieren op het Rijksarchief is het ontwerpcompendium niet meer aanwezig. Toen het in Mei te Batavia aankwam, werd het ter lezing en bestudeering rondgezonden bij alle leden der Hooge Regeering. Nadat vervolgens bij de besprekingen in Rade een aantal wijzigingen waren aangebracht, werd het goedgekeurd en van kracht verklaard bij de volgende resolutie van 31 December 1750 :

„Het compendium der Javase wetten, zo omtrend crimineele als civile zaaken door de ministers te Samarang in Mey des voorleeden jaers overgesonden, en vermeld by d' aparte brief van den gouverneur, van den 10en April bevoorens, onder d' heeren leeden ter lecture rondgeweest zijnde, en weder binnengekomen, mitsgaders over den inhoude van dien gebesoigneerd zijnde, zo is, nadat hetselve van eenige absurditeyten en duysterheden gesuyvert was, verstaen 't zelve t' approbeeren en te laten strekken tot een wetboek voor den Samarangsen Landraat, omtrent de regtsoeffening over 's Compagnies Javaanse onderdaanen".

Het draagt tot titel: „Compendium der voornaamste Javaansche wetten, nauwkeurig getrokken uit het Mahometaanse wetboek Mogharaer, en sooveel mogelijk met het Goddelyke, natuurlyke en borger- 
regt sodanig samengebragt, dat daarna, ongekrenkt de Javasche gewoontens en gebruykelijkheden, den Samarangschen landraad over de onderdaanen van 's Compagnies landen en districten regt en justitie soude kunnen oeffenen, en de crimineele zaken, soals de civile, behandelen".

Over het compendium zelf behoeven wij hier niets meer te zeggen; het is eenige malen gedrukt en beoordeeld. Zie Van Vollenhoven, De Ontdekking van het Adatrecht, blz. 9, en de daar genoemde litteratuur; Het Adatrecht van Ned.-Indië I, blz. 16, 125; 506; II, blz. 820. Men vindt het ook bij Van der Chijs, Ned. Indisch Plakaatboek VI, blz. 14 en volgende.

Wat den Landraad betreft, vonden wij nog een resolutie van 13 Februari 1776, die bepaalt, dat een deel der door dien raad op te leggen boeten ten voordeele zal komen van het te Semarang gestichte proveniershuis.

Tot slot willen wij nog enkele bizonderheden mededeelen over een mislukte poging van den Gouverneur-Generaal Jacob Mossel, 17501761, om te komen tot oprichting van Landraden in West-Java. In verband met een reeks maatregelen, welke genoemde GouverneurGeneraal na het beëindigen van den grooten Bantamschen opstand nam, tot verbetering der toestanden in het Jacatrasche bovenland en de Preangerlanden, stelde hij primo October 1754 in Rade van Indië voor ${ }^{1}$ ), ,nademaal de administratie der Justitie onder den inlander wat nader gereguleert en gemackelyker voor hun gemaakt diende te werden, dan deselve tot dusverre voor hun geweest is", om in elk district uit de geschikste hoofden ,tien tot onder-landraden te verkiezen, tot het aanhoren der klagten en saken, die in hare landen voorvallen, en 't examineeren derselve, om de sodanige, die van geen groot belang zijn, met haar tienen by de meeste stemmen de facto af te doen volgens sekere regulen en ordres, zo aangaande het regt, als de successie, erffenis en gemeenschap, door ervaren staat- en landkundige byeen te brengen, om in de inlandsche talen gedrukt te werden". Verder zou dan uit de voorzitters dier onder-landraden wederom een tiental gekozen worden, welke een Landraad zouden vormen "tot het termineeren van sware en lijfstraffelyke zaken”, welke Landraad zitting zou houden in het district, daar het delict zich had voorgedaan „of wel ter fortresse Meester Cornelis”. Wat ten

1) Zie Van der Chijs, Nederlandsch-Indisch Plakaatboek, VI, blz. 735 e.v. 
slotte ,capitale lijf- en halssaken” betreft, die zou deze Landraad ten overstaan van een te benoemen boven-landdrost kunnen ,beschryven, om by Schepenen daarover te oordeelen en vonnis te vellen". Van zaken, ,die niet puur crimineel zijn”, zou beroep van den Landraad op de Schepenbank bestaan.

Mossel motiveerde dit voorstel door te wijzen op de ,veelvuldige moorden en buffel-dieveryen, die thans veelal ongestraft in de bovenlanden gepleegt werden”, op de ,verafheid” van de Bataviasche Schepenbank, wier leden bovendien zeer bezet waren door ,derselver dagelijkse occupatiën".

In Rade van Indië bleek men niet veel voor Mossel's plan te voelen. De Raad-ordinaris J. van der Waeyen, president van Schepenen, merkte op, dat de ambtsbezigheden der leden van de Schepenbank ,nu in verre na so opereux niet meer waren als wel in vorige tyden”. In verband daarmede stelde hij voor, aan Mossel's bezwaren in zake de rechtspraak over inheemschen tegemoet te komen, door op bepaalde dagen twee Schepenen met den landdrost zitting te doen houden op Meester Cornelis, „ter bediening der justitie aldaar”, althans gedurende ,de goede of Oostmousson" als de wegen voor de heeren behoorlijk begaanbaar waren; in den regentijd konden ze te Weltevreden zitting houden. Deze bizondere rechtbank kon dan worden gequalificeerd in civile zaken tot 50 rijksdaalders; in crimineele „,niet verder te gaan dan het hooren van getuygen, beleggen van stukken, etc.”. Dit voorstel werd aangenomen, en hiermede waren de Landraden van de baan.

Hoewel dus de hoofdstrekking van Mossel's voorstel niet was aangenomen, besloot niettemin de Raad van Indië op 7 November daaraanvolgende ${ }^{1}$ ), ,aan alle de officieren en hoofden der respectieve inlandsche natiën, in dese colonie sig bevindende, te ordonneeren om ieder in den haren te colligeren en in hunne eygene tale schriftelijk op te geven hunne civile wetten en gewoontes, waarna zij zig in 't gemeen komen te reguleeren omtrent het decideeren van geschillen, tusschen hunne onderhorige ontstaande, insonderheit betreffende het poinct van successie en alle verdere erffenissen en besterffenissen, gemeenschap van goederen van personen, zig in den huwelyken staat begevende, en wat dienaangaande verder by hun in gebruyk is, met ordre om alle de voorschr. documenten over te geven aan den Commissaris over den inlander, die by dese gelast werd deselve te con-

1) Van der Chijs, VI, blz. 753 en volgende.

D1. 89. 
fronteren, in hoeverre die opgiften accorderen, ten eynde daarvan te formeeren eene duydelyke descriptie, onder gepaste tituls afgedeelt, ter nadere dispositie deser regeering".

Alle besluiten, op de Jacatrasche landen betrekking hebbende, dus ook de bovengenoemde, werden bij plakkaat van 13 December 1754 tot wet verheven.

De gecommitteerde over den Inlander, Diederik Willem Freyer, diende begin 1756 een compendium in, dat volgens resolutie van 24 Februari in handen werd gesteld van de buitengewone Raden Pieter van de Velde en Reinier de Klerck, ter controle en revisie. Toen Van de Velde 7 Augustus 1759 stierf, was die revisie nog niet afgeloopen; er moest heel wat worden gewijzigd, getuige de volgende resolutie van 25 Maart 1760 :

„Door den overleden gecommitteerde tot en over de zaeken van den Inlander in voldoening van 't placaat dezer Regeering van den 13 December 1754 met behulp van eenige Machomethaense priesters en officieren der campongs geformeert en onder behoorlyke tituls byeengebragt zijnde een compendium der civile wetten en gewoontens, waerna de Mahometanen zig in 't beslissen der onder hen voorkomende geschillen gemeenlijk komen te reguleeren, inzonderheyd betreffende ' $t$ poinct der successie, mitsgaders alle verdere erffenissen en besterffenissen, item de huwelyken, scheydingen etc., en vervolgens by besluyt van den 24 February 1756 nodig geoordeelt en verstaan zijnde, bevorens over den inhoud van gemelt compendium te disponeeren, de heeren Raden extra-ordinaris Van de Velde en De Klerk te versoeken en te committeeren, om 't zelve eens nader te revideren, en ten dien eynde met de Inlandsche capiteyns en priesters, nevens zodanige andere Machometaansche wetgeleerde, te consuleeren, als Haer $\mathrm{Ed}^{\mathrm{s}}$ nodig zouden komen te oordeelen, mitsgaders die revisie zedert door voormelde heer De Klerk, mits het intusschen voorgevallen sterfgeval van den heer Van de Velde, ten effecte gebragt, en 't gemelde compendium, nevens Zijn Ed's over zommige van de articulen gemaekte aenmerkingen weder ingedient zijnde, waerby Zijn Ed. komt te verklaeren de verzameling, vervat in 't eerste hoofddeel, handelende van de successie, erf- en besterffenissen, al zeer nauwkeurig gevonden te hebben, in zo verre dat alles, volgens 't algemeen gevoelen der priesters, voldoende, en overeenkomende met het onder haer berustende wetboek geoordeelt is geworden, dog wat het tweede hoofddeel, van den huwelyken staat etc., betreft, Zijn Ed. voorgekomen te zijn, dat de gecommitteerde voormelt zomtijds van den text 
geweken, of door de commandants der campongs, dan wel de priesters, misleyd te wezen, volgens 't geene Zijn Ed. op diverse articulen komt te remarqueeren, zo is, nadat het meergemelte schriftuur, nevens de voorschr. aanmerkingen, by de heeren leden ter lecture geweest en weder binnengekomen waeren, goedgevonden en verstaan, gemelte Machometaansche wetten met deze en geene alteratiën en veranderingen, zo uytgedagte aenmerkingen, als die gedurende de deliberatie voorgebragt en noodzakelijk geoordeelt wierden, te approbeeren en dusdanig in ordre te laten schikken, om vervolgens door den druk in de Nederduytsche en Maleysche talen gemeen gemaekt en geobserveert te werden, daer en zo 't behoord”.

Het compendium-Freyer, zooals het ter onderscheiding van het Semarangsche wel genoemd wordt, is opgenomen in de Nieuwe Statuten van Batavia, van 1766. Men vindt het afgedrukt in Ned.-Indisch Plakaatboek VII, blz. 392 en volgende. Voor zijn beteekenis en toepassing zie men Van Vollenhoven, Het Adatrecht van Nederlandsch Indië, I, blz. 16--17, 19 en 125; ook De Haan, Priangan IV, blz. $680-681$.

Ten slotte de opmerking, dat de bizondere rechtbank te Meester Cornelis bij resolutie van 21 Maart 1766 werd opgeheven. 
